\title{
Uji Aktivitas Antiseptik Ekstrak Etanol Daun Sirih (Piper betle Linn.) dalam Obat Kumur terhadap Staphylococcus aureus secara in Vitro
}

\author{
Antiseptic Activity Test Extract of Betel Leaf (Piper betle Linn.) \\ in Mouthwash Against Staphylococcus aureus in Vitro
}

\author{
Almasyhuri*, Dian Sundari \\ Pusat Penelitian dan Pengembangan Biomedis dan Teknologi Dasar Kesehatan, Jakarta, Indonesia \\ *E-mail: almasyhuri@ymail.com
}

Diterima: 28 Agustus 2018

Direvisi:26 September 2018

Disetujui: 23 Oktober 2018

\begin{abstract}
Abstrak
Daun sirih (Piper betle Linn.) sangat populer dalam kehidupan masyarakat di Indonesia. Daun sirih berguna untuk kesehatan gigi dan sering digunakan sebagai obat kumur; menghilangkan bau badan dan mulut; mengobati sariawan, mimisan, gatal-gatal, koreng dan keputihan pada wanita. Rongga mulut merupakan tempat berkumpulnya bakteri. Bila terjadi penurunan imunitas bakteri yang semula bersifat komensal dapat berubah menjadi patogen sehingga dapat menimbulkan infeksi. Bakteri yang biasa terdapat dalam rongga mulut salah satunya adalah Staphylococcus aureus. Bakteri ini memiliki kemampuan untuk menempati dan membentuk biofilm pada biomaterial yang menyebabkan resistensi terhadap antimikroba, dengan demikian membuat mereka sulit untuk memberantas host yang terinfeksi S. Aureus Berbagai penelitian terdahulu melaporkan adanya multidrug resisten dari golongan S.aureus yang dapat menimbulkan kematian, sehingga untuk mengatasi bakteri tersebut dilakukan penelitian aktivitas antiseptik ekstrak etanol daun sirih terhadap S.aureus secara in vitro. Pengujian dilakukan dengan metode koefisien fenol menggunakan bakteri S. auereus ATCC 25923. Sebagai pembanding adalah obat kumur dengan povidon iodine yang beredar dipasaran. Hasil penelitian menunjukkan bahwa obat kumur yang mengandung ekstrak etanoldaun sirih memiliki nilai koefisien fenol 1,87 sedangkan obat kumur povidon iodine mempunyai nilai koefisien fenol 1,0. Terlihat bahwa obat kumur yang mengandung ekstrak etanol daun sirih mempunyai efektifitas antiseptik lebih tinggi daripada obat kumur pembandingnya.
\end{abstract}

Kata kunci : Antiseptik; Ekstrak daun sirih; Obat kumur; S. aureus.

\begin{abstract}
Betle leaf (Piper betle Linn.) is very popular in Indonesia. Betle leaf is useful for dental health and frequently used as mouthwash; to eliminate body and mouth odor; treats mouth ulcer, nosebleed, itching, ulceration and vaginal discharge in women. An oral cavity is a place for bacteria. If there is a bacterial immunity reduction, that was originally commensal bacteria can turn into a pathogen that cause infection. One of bacteria that commonly found in the oral cavity is Staphylococcus aureus. The bacteria have the ability to occupy and form biofilm on biomaterials that cause resistant to antimicrobials, thus making it difficult to eradicate host that is infected by $S$. aureus. Previous study reported a multidrug resistant of $S$. aureus that could cause death, that to overcome it, betle leaves extract ethanol in vitro antiseptic test to S.aureus was conducted. The test was conducted by the phenol coefficient method using S. auereus ATCC 25923 bacteria. Povidone iodine mouthwash that is circulated in the market is used as a comparison. The results showed that mouthwash containing ethanol extract of betle leaf had a phenol coefficient value of 1.87 while povidone iodine mouthwash as a comparison, had a phenol coefficient of 1.0. Mouthwash containing ethanol extract of betle leaf had higher antiseptic effectiveness than the comparative mouthwash.
\end{abstract}

Keywords: Antiseptic; Betle leaf extract; Mouthwash; S. aureus. 


\section{PENDAHULUAN}

Sirih (Piper betle Linn.) termasuk familia Piperaceae. Tradisi makan sirih sangat populer dalam kehidupan masyarakat di Indonesia. Sirih berguna untuk kesehatan gigi dan menghilangkan bau badan dan bau mulut yang tidak sedap, sebagai obat kumur, sariawan, mimisan, gatal-gatal, koreng dan mengobati keputihan pada wanita. Daun sirih mempunyai aroma yang khas dengan kandungan minyak atsiri 4,2\%., Komponen utama minyak atsiri adalah senyawa fenol yaitu betlephenol dan kavikol yang merupakan senyawa aromatik, dan senyawa turunannya seperti kavibetol, karvakol, eugenol, allilpyrocatechol dan ketekin. Kavikol merupakan komponen paling banyak ditemui pada daun sirih dan menyebabkan bau khas sirih. Selain itu daun sirih mengandung suatu seskuiterpen, diastase, tannin, gula dan pati. Senyawa fenol yang terkandung dalam minyak atsiri daun sirih bersifat antimikroba dan antijamur yang kuat dan efektif menghambat pertumbuhan beberapa jenis bakteri. $^{2,3}$

Rongga mulut dan gigi merupakan bagian tubuh yang memiliki fungsi penting dalam kaitannya dengan kesehatan tubuh. Dengan menjaga kesehatan mulut dan gigi secara tidak langsung telah mengurangi resiko terkena penyakit yang menyangkut kesehatan tubuh khususnya kesehatan rongga mulut dan gigi. Masalah mulut yang sering muncul adalah bau mulut, sariawan dan infeksi mulut, selain itu ditemukan pula masalah lain seperti mulut kering, radang gusi dan kanker mulut. ${ }^{4}$

Rongga mulut merupakan tempat berkumpulnya bakteri, bila terjadi penurunan imunitas bakteri yang semula bersifat komensal dapat berubah menjadi patogen sehingga dapat menimbulkan infeksi, Bakteri yang biasa terdapat dalam rongga mulut salah satunya adalah Staphylococcus aureus (S. aureus). Bakteri ini memiliki kemampuan untuk menempati dan membentuk biofilm pada biomaterial yang menyebabkan resistensi terhadap antimikroba, dengan demikian membuat mereka sulit untuk memberantas host yang terinfeksi. ${ }^{5}$ S. aureus saat ini juga menjadi penyebab utama infeksi nosokomial. Karena banyaknya pasien yang dirawat di luar rumah sakit, maka penyebarannya dimasyarakat juga semakin meningkat. Penelitian terdahulu melaporkan adanya multidrug resisten dari golongan S.aureus yang dapat menimbulkan kematian, sehingga berbagai penelitian untuk mengatasi hal ini sangat diperlukan. ${ }^{6}$ Untuk mengatasi bakteri tersebut dilakukan penelitian aktivitas antiseptik obat kumur terhadap bakteri $S$. aureus.

Obat kumur adalah sediaan berupa larutan yang digunakan untuk membersihkan rongga mulut dan gigi secara lebih bersih dibandingkan dengan sikat gigi biasa. Obat kumur memiliki kandungan dasar berupa air, agen pembersih, bahan pengharum, pewarna dan alkohol. ${ }^{7,8}$ Berdasarkan kandungan bahan aktif yang terkandung di dalamnya, obat kumur dapat digolongkan menjadi beberapa jenis, yaitu : obat kumur yang mengandung bahan aktif antiseptik/antimikroba seperti povidone iodine, cetylpyridinium chloride berfungsi mengontrol pertumbuhan bakteri pada mulut, mengurangi plak, menyembuhkan radang gusi, dan menghilangkan bau mulut. Ada obat kumur yang bahan aktifnya fluoride, berfungsi membantu mencegah terbentuknya lubang gigi dan mencegah kerusakan gigi. Bahan pewangi bisa menjadi salah satu kandungan pada obat kumur. Bahan aktif ini akan berperan sebagai bahan kimia yang mampu menetralisir bau mulut. ${ }^{8}$

Obat kumur yang beredar di pasaran adalah obat kumur yang mengandung bahan kimia seperti alkohol dan bahan antiseptik/antimikroba. Alkohol sebagai zat pelarut dapat menimbulkan beberapa efek seperti sensasi terbakar ketika berkontak dengan mukosa dan rasa kering pada mukosa mulut. Pengunaan yang berlebihan bahan antiseptik obat kumur akan merusak keseimbangan bakteri dalam mulut karena kandungan alkohol dan antiseptiknya membunuh mikroorganisme dalam mulut termasuk mikroorganisme normal yang ada 
di dalam mulut. ${ }^{9}$ Efek penggunaan obat kumur berbahan kimia sebenarnya dapat diminimalisir dengan menggunakan bahan alami, salah satu bahan alami yang dapat digunakan yaitu daun sirih. Kandungan yang terdapat pada daun sirih berupa minyak atsiri yang didalamnya terdapat senyawa fenol yang dapat menghambat pertumbuhan bakteri pada mulut. ${ }^{9,10}$

Telah dilakukan uji daya antiseptik ekstrak etanol daun sirih formula obat kumur terhadap bakteri $S$. aureus secara in vitro. Pengujian dilakukan dengan metode koefisien fenol menggunakan bakteri $S$. aureus ATCC 25923. Sebagai pembanding digunakan obat kumur yang beredar di pasaran dengan bahan aktif povidon iodine $1 \%$.

\section{METODE}

Penelitan ini merupakan eksperimen laboratorium yang dilakukan di laboratorium mikrobiologi Gizi Bogor. Pengujian ekstrak etanol daun sirih sebagai antiseptik dilakukan dengan metode koefisien fenol menggunakan bakteri $S$. auereus ATCC 25923.

\section{Alat dan bahan}

Peralatan yang digunakan dalam penelitian ini terdiri dari oven (Memmert), rotary evaporator (Buchi) dan tabung reaksi steril,

Bahan uji adalah daun sirih (Piper betle Linn.) yang didapat dari daerah Depok. Bakteri Staphylococcus aureus ATCC 25923 berumur 24 jam dari Laboratorium Teknologi Bio Industri PUSPITEK Serpong. Bahan kimia yang digunakan adalah etanol; Nutrien Agar (oxoid), Nutrien Broth; Tween 80 (Merck), Span 80 Gliserin; fenol (Merck), $\mathrm{NaCl}$ (Merck), aquades steril, obat kumur yang mengandung zat aktif Povidon iodine 1\%

\section{Cara kerja}

\section{Pembuatan ekstrak etanol daun sirih}

Sebanyak $3 \mathrm{~kg}$ daun sirih segar dibersihkan dan dicuci dengan air, kemudian dirajang halus dan dijemur di bawah sinar matahari langsung hingga kering. Dari $3 \mathrm{~kg}$ daun sirih segar menghasilkan simplisia sebanyak $1,5 \mathrm{~kg}$ kemudian simplisia dihaluskan hingga menjadi serbuk. Serbuk daun sirih ini diekstraksi dengan cara maserasi menggunakan etanol $70 \%$ sehingga didapat ekstak kental untuk kemudian dihitung rendemen ekstrak yang diperoleh. ${ }^{8}$

\section{Pembuatan formula obat kumur dengan ekstrak dan tanpa ekstrak daun sirih}

Gliserin sebanyak $20 \mathrm{ml}$ ditambahkan ke dalam 2 g ekstrak daun sirih sambil diaduk hingga merata, kemudian ditambahkan 0,5 $\mathrm{ml}$ Tween 80 dan $1 \mathrm{ml}$ span 80, aduk campuran hingga larut dan $100 \mathrm{ml}$ air ditambahkan agar larutan menjadi homogen. Formulasi obat kumur tanpa ekstrak daun sirih dibuat dengan cara gliserin sebanyak $20 \mathrm{ml}$ ditambahkan $0,5 \mathrm{ml}$ Tween 80 dan 1 ml span 80, kemudian diaduk, tambahkan $100 \mathrm{ml}$ air, aduk agar larutan menjadi homogen.

Pembuatan stok bahan uji formula obat kumur ekstrak dan tanpa ekstrak daun sirih

Dari hasil pembuatan formula obat kumur ekstrak dan obat kumur tanpa ekstrak daun sirih di atas, masing-masing diambil sebanyak $5 \mathrm{ml}$ sebagai stok bahan uji.

\section{Pembuatan stok obat kumur mengandung povidon iodine sebagai pembanding}

Sebagai pembanding antiseptik digunakan obat kumur yang mengandung bahan aktif povidon iodine 1\%. Diambil 5 $\mathrm{ml}$ obat kumur povidon iodine sebagai stok bahan uji.

\section{Pembuatan larutan stok fenol}

Larutan stok fenol dibuat dengan cara melarutkan 5 gram kristal fenol dengan 100 $\mathrm{ml}$ air suling steril, maka didapat larutan fenol dengan konsentrasi $5 \% .^{11,12}$ 
Pengenceran obat kumur ekstrak daun sirih dan obat kumur povidon-iodine

Sebanyak $1 \mathrm{ml}$ larutan obat kumur ektrak etanol $70 \%$ daun sirih dimasukkan ke dalam tabung reaksi steril kemudian diencerkan dengan air suling steril dengan berbagai konsentrasi yaitu $1: 20 ; 1: 30 ; 1: 40$; $1: 50 ; 1: 60 ; 1: 70 ; 1: 80 ; 1: 90 ; 1: 100 ; 1: 110$; $1: 150 ; 1: 200 ; 1: 250$. Larutan tersebut dihomogenkan kemudian dipindahkan ke tabung steril lain masing-masing sebanyak $5 \mathrm{ml}$. Lakukan pengenceran pada obat kumur povidon iodine dengan cara yang sama seperti pengenceran obat kumur ekstrak daun sirih. ${ }^{13,14,15}$

\section{Pengenceran fenol 5\%}

Sepuluh tabung steril disiapkan dengan diberi nomor (no.) 1-10. Tabung 1-5 diberi air suling steril sebanyak 5; 6; 7; 8 dan $9 \mathrm{ml}$. Kemudian dari tabung 1-5 masing-masing diberi pengenceran fenol (1:20) sebanyak 2 $\mathrm{ml}$ dan homogenkan. Sebanyak $5 \mathrm{ml}$ larutan pada tabung 1 dipindahkan ke dalam tabung no. 6 , demikian juga dari tabung no. 2 ke tabung no. 7; dari tabung no. 3 ke tabung no. 8; dari tabung no. 4 ke tabung no. 9 dan dari tabung no. 5 ke tabung no. 10, maka didapat pengenceran larutan fenol 1:70; $1: 80 ; 1: 90 ; 1: 100$; dan $1: 110 .^{14,15}$

Uji koefisien fenol larutan stok (stok fenol $5 \%$, obat kumur ekstrak etanol $\mathbf{7 0 \%}$ daun sirih, obat kumur tanpa ekstrak daun sirih, obat kumur povidon iodine)

Sebanyak $5 \mathrm{ml}$ stok fenol $5 \%$ dimasukkan dalam tabung steril lalu ditambahkan 0,5 $\mathrm{ml}$ biakan kaldu bakteri $S$. aureus, dihomogenkan kemudian dalam waktu 5, 10, 15 menit dipindahkan satu mata ose ke tabung yang berisi kaldu nutrien broth (NB) steril, dihomogenkan lalu diinkubasi selama 24-48 jam pada suhu 30-37 ${ }^{\circ} \mathrm{C}$, diamati ada tidaknya pertumbuhan bakteri pada setiap tabung. Uji koefisien fenol untuk stok obat kumur ektrak daun sirih, stok obat kumur tanpa ekstrak daun sirih dan stok obat kumur povidon-iodine terhadap $S$. aureus perlakuannya sama dengan uji koefisien fenol pada stok fenol 5\%. ${ }^{15}$

\section{Uji koefisien fenol dari pengenceran fenol} $5 \%$, obat kumur ekstrak daun sirih dan obat kumur povidon iodine

Sebanyak $5 \mathrm{ml}$ larutan pengenceran fenol $5 \%$ di atas dimasukkan ke dalam tabung steril dan ditambahkan $0,5 \mathrm{ml}$ biakan kaldu bakteri $S$. aureus kemudian dihomogenkan. Dalam waktu 5, 10, 15 menit dipindahkan satu mata ose ke dalam tabung yang berisi kaldu NB steril, dihomogenkan dan diinkubasi selama 2448 jam pada suhu $30-37{ }^{\circ} \mathrm{C}$, kemudian diamati terlihat ada tidaknya pertumbuhan bakteri pada setiap tabung. Uji koefisien fenol untuk pengenceran obat kumur ektrak daun sirih, pengenceran obat kumur povidon-iodine perlakuannya sama dengan uji koefisien fenol pada pengenceran fenol $5 \% .^{15}$

Hasil uji koefisien fenol adalah hasil bagi pengenceran tertinggi dari bahan uji terhadap pengenceran larutan fenol yang mematikan bakteri dalam 10 menit tetapi tidak mematikan dalam 5 menit. $^{15}$ Dalam rumus sebagai berikut:

Pengenceran tertinggi bahan uji yang mematikan dalam waktu 10 menit tetapi tidak mematikan dalam 5 menit

Koefisien fenol $=$

Pengenceran tertinggi larutan fenol yang mematikan dalam waktu

10 menit tetapi tidak mematikan dalam 5 menit 


\section{HASIL DAN PEMBAHASAN}

Hasil ekstraksi dengan cara maserasi dari $3 \mathrm{~kg}$ daun sirih segar dengan etanol $70 \%$ didapat 24 gram ekstrak kental. Rendemen ekstrak daun sirih dapat dilihat pada Tabel 1.

Hasil ekstraksi daun sirih menggunakan etanol $70 \%$ memberikan rendemen $4,8 \%$. Rendemen yang diperoleh cukup kecil dimana rendemen yang kecil akan menghasilkan ekstrak yang sedikit. Penelitian sebelumnya memperoleh rendemen ekstrak etanol daun sirih hijau dengan cara maserasi sebesar $14,16 \%$. $^{16}$ Lebih rendahnya rendemen pada penelitian ini dibanding penelitain sebelumnya kemungkinan dipengaruhi oleh beberapa faktor antara lain ukuran partikel, jenis pelarut, metode, dan lama ekstraksi. ${ }^{17}$

Penggunaan etanol $70 \%$ dalam pembuatan ekstrak dikarena kapang dan kuman sulit tumbuh, tidak beracun, netral dan absorbsinya bagus. Etanol dapat bercampur dengan air pada segala perbandingan dan hanya membutuhkan panas sedikit untuk pemekatannya. Etanol dapat melarutkan alkaloid basa, minyak atsiri, glikosida, kurkumin, antrakinon, flavonoid, steroid, damar dan klorofil, sedangkan lemak, malam, tanin dan saponin hanya sedikit larut. ${ }^{8,11}$

Pengamatan aktivitas antiseptik stok fenol 5\%, stok formula obat kumur dengan ekstrak daun sirih, stok obat kumur povidon iodine dan stok formula obat kumur tanpa ekstrak daun sirih terhadap $S$. aureus dapat dilihat pada Tabel 2.

Berdasarkan hasil pada Tabel 2 stok fenol 5\%, stok formula obat kumur ekstrak daun sirih dan stok obat kumur povidon iodine pada semua waktu kontak dapat mematikan bakteri, sedangkan pada formula obat kumur tanpa ekstrak daun sirih terlihat adanya pertumbuhan bakteri. Berdasarkan hal tersebut, larutan stok fenol, obat kumur ekstrak daun sirih, dan obat kumur povidon iodine bersifat antiseptik terhadap bakteri $S$. aureus. Formula obat kumur tanpa ekstrak daun sirih tidak dapat menghambat pertumbuhan bakteri $S$. aureus, dan untuk selanjutnya formula obat kumur tanpa ekstrak daun sirih ini tidak digunakan lagi untuk pengujian selanjutnya.

Tabel 1. Rendemen ekstrak etanol 70\% daun sirih (Piper betle Linn.)

\begin{tabular}{ccccc}
\hline Bahan ekstrak & $\begin{array}{c}\text { Daun segar } \\
\text { (gram) }\end{array}$ & $\begin{array}{c}\text { Serbuk } \\
(\text { gram })\end{array}$ & $\begin{array}{c}\text { Ekstrak kental } \\
\text { (gram) }\end{array}$ & $\begin{array}{c}\text { Rendemen } \\
(\%)\end{array}$ \\
\hline Daun sirih & 3000 & 1500 & 24 & 4,8 \\
\hline
\end{tabular}

Tabel 2. Pengamatan aktivitas antiseptik ke empat stok bahan uji terhadap bakteri S. aureus pada menit ke-5, 10 dan 15

\begin{tabular}{|c|c|c|c|c|c|c|c|c|c|c|c|c|}
\hline \multirow[b]{3}{*}{ Bakteri } & \multicolumn{12}{|c|}{ Waktu kontak } \\
\hline & \multicolumn{4}{|c|}{ Menit ke-5 Bahan uji } & \multicolumn{4}{|c|}{ Menit ke-10 Bahan uji } & \multicolumn{4}{|c|}{ Menit ke-15Bahan uji } \\
\hline & 1 & 2 & 3 & 4 & 1 & 2 & 3 & 4 & 1 & 2 & 3 & 4 \\
\hline S. aureus & - & - & - & + & - & - & - & + & - & - & - & + \\
\hline \multicolumn{13}{|c|}{$\begin{array}{l}\text { Keterangan : } \\
\text { - : tidak mengandung bakteri } S \text {. aureus } \\
+ \text { : mengandung bakteri } S \text {. aureus } \\
\text { Bahan uji } 1: \text { stok fenol } 5 \% \\
\text { Bahan uji } 2: \text { stok formula obat kumur ekstak daun sirih. } \\
\text { Bahan uji } 3: \text { stok obat kumur Povidon iodine. } \\
\text { Bahan } \text { uij } 4 \cdot \text { stok formula ohat kumur tanna ekstrak daun }\end{array}$} \\
\hline
\end{tabular}


Tabel 3. Hasil pengamatan aktivitas antiseptik obat kumur ekstrak etanol daun sirih dan fenol terhadap bakteri $S$. aureus

\begin{tabular}{|c|c|c|c|c|c|c|c|c|c|c|c|c|c|c|c|c|c|c|}
\hline \multirow{4}{*}{ Pengenceran } & \multicolumn{9}{|c|}{ Obat kumur ekstrak daun sirih } & \multicolumn{9}{|c|}{ Fenol } \\
\hline & \multicolumn{9}{|c|}{ Waktu kontak dan ulangan } & \multicolumn{9}{|c|}{ Waktu kontak dan ulangan } \\
\hline & \multicolumn{3}{|c|}{ Menit ke-5 } & \multicolumn{3}{|c|}{ Menit ke-10 } & \multicolumn{3}{|c|}{ Menit ke-15 } & \multicolumn{3}{|c|}{ Menit ke-5 } & \multicolumn{3}{|c|}{ Menit ke-10 } & \multicolumn{3}{|c|}{ Menit ke-15 } \\
\hline & 1 & 2 & 3 & 1 & 2 & 3 & 1 & 2 & 3 & 1 & 2 & 3 & 1 & 2 & 3 & 1 & 2 & 3 \\
\hline $1: 20$ & - & - & - & - & - & - & - & - & - & - & - & - & - & - & - & - & - & - \\
\hline $1: 30$ & - & - & - & - & - & - & - & - & - & - & - & - & - & - & - & - & - & - \\
\hline $1: 40$ & - & - & - & - & - & - & - & - & - & - & - & - & - & - & - & - & - & - \\
\hline $1: 50$ & - & - & - & - & - & - & - & - & - & - & - & - & - & - & - & - & - & - \\
\hline $1: 60$ & - & - & - & - & - & - & - & - & - & - & - & - & - & - & - & - & - & - \\
\hline $1: 70$ & - & - & - & - & - & - & - & - & - & - & - & - & - & - & - & - & - & - \\
\hline $1: 80$ & - & - & - & - & - & - & - & - & - & + & + & + & - & - & - & - & - & - \\
\hline $1: 90$ & - & - & - & - & - & - & - & - & - & + & + & + & + & + & + & + & + & + \\
\hline $1: 100$ & - & - & - & - & - & - & - & - & - & + & + & + & + & + & + & + & + & + \\
\hline $1: 110$ & - & - & - & - & - & - & - & - & - & + & + & + & + & + & + & + & + & + \\
\hline $1: 150$ & + & - & - & - & - & - & - & - & - & + & + & + & + & + & + & + & + & + \\
\hline $1: 200$ & + & + & + & + & + & - & + & - & - & + & + & + & + & + & + & + & + & + \\
\hline $1: 250$ & + & + & + & + & + & + & + & + & + & + & + & + & + & + & + & + & + & + \\
\hline
\end{tabular}

Keterangan : - : tidak mengandung bakteri $S$. aureus

+ : mengandung bakteri $S$. aureus

1,2,3: ulangan 1,2 dan 3

Tabel 4. Hasil pengamatan aktivitas antiseptik obat kumur povidon iodine dan fenol terhadap bakteri S. aureus

\begin{tabular}{|c|c|c|c|c|c|c|c|c|c|c|c|c|c|c|c|c|c|c|}
\hline \multirow{4}{*}{ Pengenceran } & \multicolumn{9}{|c|}{ Obat kumur povidon iodine } & \multicolumn{9}{|c|}{ Fenol } \\
\hline & \multicolumn{9}{|c|}{ Waktu kontak dan ulangan } & \multicolumn{9}{|c|}{ Waktu kontak dan ulangan } \\
\hline & \multicolumn{3}{|c|}{ Menit ke-5 } & \multicolumn{3}{|c|}{ Menit ke-10 } & \multicolumn{3}{|c|}{ Menit ke-15 } & \multicolumn{3}{|c|}{ Menit ke-5 } & \multicolumn{3}{|c|}{ Menit ke-10 } & \multicolumn{3}{|c|}{ Menit ke-15 } \\
\hline & 1 & 2 & 3 & 1 & 2 & 3 & 1 & 2 & 3 & 1 & 2 & 3 & 1 & 2 & 3 & 1 & 2 & 3 \\
\hline $1: 20$ & - & - & - & - & - & - & - & - & - & - & - & - & - & - & - & - & - & - \\
\hline $1: 30$ & - & - & - & - & - & - & - & - & - & - & - & - & - & - & - & - & - & - \\
\hline $1: 40$ & - & - & - & - & - & - & - & - & - & - & - & - & - & - & - & - & - & - \\
\hline $1: 50$ & - & - & - & - & - & - & - & - & - & - & - & - & - & - & - & - & - & - \\
\hline $1: 60$ & - & - & - & - & - & - & - & - & - & - & - & - & - & - & - & - & - & - \\
\hline $1: 70$ & - & - & - & - & - & - & - & - & - & - & - & - & - & - & - & - & - & - \\
\hline $1: 80$ & + & - & - & - & - & - & - & - & - & + & + & + & - & - & - & - & - & - \\
\hline $1: 90$ & + & + & + & + & + & - & - & - & - & + & + & + & + & + & + & + & + & + \\
\hline $1: 100$ & + & + & + & + & + & + & + & + & + & + & + & + & + & + & + & + & + & + \\
\hline $1: 110$ & + & + & + & + & + & + & + & + & + & + & + & + & + & + & + & + & + & + \\
\hline $1: 150$ & + & + & + & + & + & + & + & + & + & + & + & + & + & + & + & + & + & + \\
\hline $1: 200$ & + & + & + & + & + & + & + & + & + & + & + & + & + & + & + & + & + & + \\
\hline $1: 250$ & + & + & + & + & + & + & + & + & + & + & + & + & + & + & + & + & + & + \\
\hline
\end{tabular}

Keterangan : - : tidak mengandung bakteri $S$. aureus

+ : mengandung bakteri $S$. aureus

1,2,3: ulangan 1,2 dan 3

Fenol merupakan bahan kimia yang dapat membunuh mikroorganisme, germisidal kuat yang telah digunakan dalam jangka waktu panjang. Fenol $\left(\mathrm{C}_{6} \mathrm{H}_{5} \mathrm{OH}\right)$ merupakan zat pembaku daya antiseptik sehingga daya antiseptik dinyatakan dengan koefisien fenol.
Koefisien fenol merupakan sebuah nilai aktivitas germisidal suatu antiseptik dibandingkan dengan efektivitas germisidal fenol. Aktivitas germisidal adalah kemampuan suatu senyawa antiseptik untuk membunuh mikroorganisme dalam jangka waktu tertentu. ${ }^{14}$ 
Untuk mengetahui efektivitas antiseptik terhadap bakteri $S$. aureus, dilakukan pengamatan terhadap aktivitas antiseptik pada pengenceran formula obat kumur ekstrak daun sirih dan pengenceran obat kumur povidon iodine terhadap fenol pada menit ke-5, ke-10, dan ke-15 menit dengan 3 kali pengulangan. Hasil pengamatan aktivitas antiseptik obat kumur ekstrak daun sirih dan obat kumur povidon iodine terhadap fenol dapat dilihat pada Tabel 3 dan 4.

Salah satu cara pengujian antiseptik adalah dengan metode pengenceran. Kekuatan antiseptik pada metode tersebut dinyatakan dengan koefisien fenol. ${ }^{8}$ Komponen utama minyak atsiri dari esktrak daun sirih adalah senyawa turunan fenol yaitu betle phenol dan kavikol. Senyawa fenol yang terkandung daun sirih bersifat antimikroba dan antijamur yang kuat dan efektif menghambat pertumbuhan beberapa jenis bakteri. ${ }^{2,3}$ Efektivitas senyawa antiseptik sangat dipengaruhi oleh konsentrasi dan lama paparannya. Semakin tinggi konsentrasi dan semakin lama paparan akan meningkatkan efektivitas senyawa antiseptik. ${ }^{3,18}$ Hasil penelitian lain menunjukkan senyawa kavikol yang memberikan bau khas daun sirih, memiliki daya membunuh bakteri lima kali lebih besar dari fenol biasa. ${ }^{13}$

Hasil pengamatan pada Tabel 3 dilanjutkan dengan menghitung koefisien fenol. Fenol memberikan efektivitas terhadap antiseptik pada pengenceran 1:80 sedangkan untuk obat kumur ekstrak daun sirih pada pengenceran 1:150. Untuk obat kumur ekstrak daun sirih menit ke-10 pada semua ulangan menghasilkan kematian bakteri, tetapi pada menit ke-5 bakteri yang tidak mati hanya pada ulangan 1 , sedangkan pada ulangan ke-2 dan ke-3 bakteri $S$. aureus mati. Oleh karena itu, perhitungan koefisien fenol tidak dapat dihitung. Pengenceran tertinggi obat kumur ekstrak daun sirih terjadi pada pengenceran 1:200 tetapi bakteri yang mati pada menit ke-10 dari tiga kali ulangan hanya terjadi satu kali yaitu pada ulangan ke-3 saja sehingga diambil kesimpulan pengenceran tertinggi obat kumur ekstrak daun sirih ini efektif sebagai antiseptik pada pengenceran 1:150 dimana pada menit ke-10 bakteri S. aureus mati pada ke tiga ulangan obat kumur ekstrak daun sirih.

Hasil pengamatan menunjukkan bahwa pengenceran obat kumur dengan povidon iodine mempunyai sifat antiseptik yang setara dengan fenol (Tabel 4). Pada pengenceran 1:80, baik obat kumur povidon iodine maupun fenol pada menit ke-10 dapat menyebabkan kematian bakteri, sedangkan obat kumur ekstrak daun sirih memberikan efektivitas antiseptik pada pengenceran 1:150.

Hasil pengamatan tersebut dilanjutkan dengan menghitung koefisien fenol untuk masing-masing obat kumur. Nilai koefisien fenol obat kumur ekstrak daun sirih adalah 1,87 (lebih dari 1) sedangkan untuk fenol dan obat kumur povidon iodine adalah 1 . Hal ini menunjukkan formula obat ekstrak daun sirih mempunyai efektivitas antiseptik yang lebih baik dibandingkan dengan fenol dan obat kumur povidon iodine.

Penelitian terdahulu dari ekstrak daun sirih menyatakan khasiat antiseptik dan antibakteri ekstrak daun sirih juga terlihat pada formulasi sediaan pasta gigi yang mengandung ekstrak daun sirih dan ekstrak kulit jeruk lemon dimana formulasi pasta gigi ini dapat menghambat pertumbahan Streptococcus mutans, dan senyawa yang berperan sebagai antiseptik ini adalah kandungan polifenol dan tannin yang terdapat dalam daun sirih. $^{14}$ Penelitian lainnya telah pula dilakukan terhadap pengamatan sediaan gel ekstrak etanol $96 \%$ daun saga $5 \%$, dimana pada menit ke-10 ekstrak tersebut dapat mematikan bakteri $S$. aures dan pada menit ke-5 bakteri tersebut tetap ada dalam sediaan. ${ }^{19}$ Pengujian terhadap toksisitas akut ekstrak daun sirih telah pula dilakukan oleh Sari dimana ekstrak etanol daun sirih masuk dalam kategori praktis tidak toksik. ${ }^{20}$ Dari hasil penelitian ini dan peneliti sebelumnya dapat dikatakan formulasi obat kumur dengan bahan ekstrak etanol daun sirih ini efektif 
sebagai antiseptik dan aman digunakan sebagai obat kumur.

\section{KESIMPULAN}

Obat kumur ekstrak etanol daun sirih secara in vitro efektif sebagai antiseptik terhadap bakteri $S$. aureus. Berdasarkan nilai koefisien fenol, obat kumur dengan ekstrak daun sirih mempunyai aktivitas antiseptik yang lebih tinggi dibandingkan dengan formula obat kumur povidon iodine yang beredar di masyarakat.

\section{UCAPAN TERIMA KASIH}

Ucapan terima kasih kami sampaikan kepada Rismawati, Drs. Erwin Affandi, dan staf lain yang telah bekerja melakukan penelitian ini, membantu dan bekerja sama dengan baik sehingga penelitian ini dapat terlaksana dan selesai dengan baik.

\section{DAFTAR RUJUKAN}

1. Iptika A. Keterkaitan kebiasaan dan kepercayaan mengunyah sirih pinang dengan kesehatan gigi. Jurnal Unair. 2014;3(1): 64-69.

2. Sumampouw O.J. Uji in vitro aktivitas antibakteri dari daun sirih. Jurnal Biomedik. 2010;2(3):187-93.

3. Dhika TS. Perbandingan efek antibakteri berbagai konsentrasi daun sirih (Piper betle Linn) terhadap Streptococcus mutans. [Skripsi]. Universitas Diponegoro; 2007.

4. Arifin M.F, Nurhidayati L, Syarmalina, Rensy. Formulasi edible film ekstrak daun sirih (Piper betle L.) sebagai antihalitosis. Prosiding Kongres Ilmiah ISFI XVII; Desember 2009:7-9.

5. Bhattacharya S, Bir R, Majumdar $\mathrm{T}$. Evaluation of multidrug resistant Staphylococcus aureus and their association with biofilm production in a tertiary care hospital, Tripura, Northeast India.Journal of Clinical and Diagnostic Research. 2015 Sept;9(9):1-5.

6. ECDC/EMEA The bacterial challenge: time to react. Stockholm: European center for diseaseprevention and control; 2009.
7. Suratmi, Juanita F. Pengaruh kumur infusum daun sirih (Piper batle L.) terhadap oral hygiene pasien bed rest di ruang Dahlia RSUD dr. Soegiri. Surya. 2016;08(03): 16-20.

8. Kementerian Kesehatan Republik Indonesia. Farmakope Indonesia. Edisi 5. Jakarta: Kementerian Kesehatan Republik Indonesia; 2014.

9. Toar AI, Posangi J, Wowor V. Daya hambat obat kumur cetylpyridinium chloride dan obat kumur daun sirih terhadap pertumbuhan Streptococcus mutans. Jurnal Biomedik. 2013 ;5(1):1638.

10. Ardianti GM. Efektivitas ekstrak daun sirih sebagai obat kumur terhadap penurunan plak indeks. [Skripsi]. Universitas Negeri Semarang; 2011.

11. Rachma M. Formulasi sediaan obat kumur yang mengandung minyak atsiri temulawak (Curcuma xanthorriza) sebagai antibakteri Porphyromonas gingivatis penyebab bau mulut. [Skripsi]. Universitas Indonesia; 2010.

12. Ansel H. Pengantar bentuk sediaan farmasi. Editor. Penerbit Universitas Indonesia,[diterjemahkan oleh Ibrahim F.] Edisi 4. Jakarta: 2005.

13. Reveny J. Daya antimikroba ekstrak dan fraksi daun sirih merah (Piper betle Linn.). Jurnal ILMU DASAR. Januari 2011;12(1);6-12.

14. Nurdianti L, Annyssya WF, Pamela YM, Novianti E, Audina M, Kurniasari E. Formulasi sediaan pasta gigi herbal kombinasi ekstrak daun sirih (Piper betle) dan kulit buah jeruk lemon (Citrus limon Burm.f) sebagai pemutih dan antiseptik pada gigi. Jurnal Kesehatan Bakti Tunas Husada. 2016;16(1): 177-187

15. Waluyo L. Teknik dasar dalam mikrobiologi. Malang: UMM Press; 2008.

16. Vifta RS,, Wansyah MA, Hati AK. perbandingan total rendemen dan skrining antibakteri ekstrak etanol daun sirih hijau (Piper betle L.) secara mikrodilusi. .Journal of Science and Applicative Technology . 2017;I(2):87-93.

17. Salamah N, Rozak, Abror MA. Pengaruh metode penyarian terhadap kadar alkaloid total daun jembirit (Tabernaemontana sphaerocarpa BL) dengan metode Spektrofotometri Visibel, Pharmaciana. Mei 2017;7(1):113-22. 
18. Saraswati D. Pengaruh konsentrasi ekstrak daun sirih terhadap daya hambat Escherichia coli. Jurnal Health \& Sport. 2011;3(2):285-362.

19. Pertiwi RD, Kristanto J , Praptiwi GA. Uji aktivitas antibakteri formulasi gel untuk sariawan dari ekstrak daun saga (Abrus precatorius Linn.) terhadap bakteri Staphylococcus aureus. Jurnal Ilmiah
Manuntung. 2016;2(2):239-47.

20. Sari WP. Uji toksisistas akut campuran ekstrak etanol daun sirih (Piper betle L.) dan ekstrak kering gambir (Uncaria gambir R. terhadap mencit putih jantan. [Skripsi]. Jakarta: Universitas Islam Negeri Syarif Hidayatullah; 2010. 